\title{
THE BRITISH SALONIKA FORCE COLLECTION AT THE
}

\section{BRITISH MUSEUM ${ }^{1}$}

Andrew Shapland

British Museum

\section{INTRODUCTION}

The archaeological activities of the British Salonika Force (and of the Allied Army of the Orient of which it was a part) are well-documented. British and French archaeologists published accounts of their discoveries (Casson 1916; Rey 1916, 191719; Gardner and Casson 1918-19; Picard 1918-19). These, in turn prompted further work after the War had ended at promising sites, notably Chauchitza (Maitland this volume). Whereas the finds from these peacetime excavations remained in Greece, antiquities found during the War were largely removed by soldiers and armies as they departed from Thessaloniki. The British Salonika Force collection, and related objects, is one such group of material which left Greece in 1919. Now in the British Museum, it comprises around 3000 objects, most of which are potsherds. This paper will seek to contextualise them in the archaeological activities of the British Salonika Force [BSF]. It will then examine the circumstances of the transfer to London in 1919 and summarise the present state of knowledge about them, before assessing their historical and archaeological significance.

\section{THE WHITE TOWER COLLECTION}

After the initial advance into Serbia of October-November 1915 had failed, the Allies entrenched themselves within the borders of Greece, still a neutral country (Wakefield 
this volume). Inevitably antiquities were found during the trench-digging of the winter of $1915 / 1916$ but it was the Greek Government's concern for the Byzantine artifacts associated with abandoned churches that provided the impetus for a formal agreement about the care of antiquities. In February 1916 the British Minister in Athens, Sir Francis Elliot, asked the British officer in charge of Intelligence in Salonika, Colonel Cunliffe Owen, to investigate. The matter was passed on to Lieutenant Ernest Gardner, Professor of Classical Archaeology at the University of London, who was serving as an intelligence officer in the Royal Naval Volunteer Reserve. ${ }^{2}$ Gardner had already persuaded Cunliffe Owen to ensure that British orders for the protection of all antiquities were issued in December 1915, but the Greek Government's intervention meant that British and French officials met with the Byzantine Ephor, Adamantios Adamantiou, to formalise arrangements (Gardner and Casson 1918-19, 10). All agreed that Greek antiquities laws were to be upheld, but that the British and French forces were to take responsibility for doing so on behalf of the Ephorate. Gardner conveyed this agreement about the care of antiquities in person to General Sarrail, commander of the Allied Forces. ${ }^{3}$ Orders were issued on 21 February 1916 which became the basis for the British and French forces' approach to archaeology in Salonika (Rey 1917-19, 13; Descamps-Lequime, this volume).

Although British and French forces were subject to the same agreement, archaeological activities were divided between the British and French zones, reflecting the semi-autonomy of the two commands. As a result finds from the British zone were kept separately from objects found by the French Army. Ernest Gardner, soon promoted to Lieutenant-Commander, was put in charge of the British finds, collected in what he called the Salonika Museum, which later became known as the BSF Museum. From February 1916 the Museum was located in the White Tower, a remnant of the Ottoman city walls on the Thessaloniki harbourfront. A photograph 
taken in April 1916 shows Lieutenant-Commander Gardner, curator of the BSF Museum, surrounded by finds made by British soldiers (Fig. 6.1). <FIGURE 6.1 HERE> During this period he often went in person to inspect the site of archaeological discoveries, and made arrangements for the finds to be transferred to the White Tower: the storage jars from Lembet in the foreground and the kothon from Aivasil (Morgan, this volume) in the background were among the first finds to be collected in this way. Gardner was keen to stress that the White Tower was chosen because it was still under Greek control, reaffirming the operation of the antiquities law (Gardner and Casson 1918-19, 11).

The BSF Museum involved a number of archaeologists who were serving in the army and navy. The three curators were Gardner, who was in charge until March 1917, followed by Lieutenant T.E. Peet, who handed over the collection to Major A.G. Wade in the autumn of the same year. Captain Stanley Casson was another archaeologist who assisted throughout his time in Macedonia. With the exception of Wade, all had been students of the British School at Athens before the War, and Gardner had served as Director until 1895. ${ }^{4}$ Gardner divided his time between the Museum and his work in Military Intelligence, which initially consisted of monitoring the Greek press and acting as a translator and intermediary when needed. In both he was closely assisted by $2^{\text {nd }}$ Lieutenant Marcus Tod, University Lecturer in Greek Epigraphy at Oxford (Gill 2011b, 393-95). Despite their expertise none of those involved with the Museum were appointed to archaeological work full-time. As another British officer, himself an entomologist, remarked: 'Their military duties, it is true, had nothing in common with their special studies, and the late Professor Peet was detailed to count empty petrol tins. But the military authorities recognized the importance of the opportunity, and gave every facility for the prosecution of archaeological research' (Burr 1935, 212). 
Certainly transport and personnel were made available to enable Gardner to collect objects found.

Gardner handed over the curatorship to Peet after he was appointed Intelligence Officer on the S.S. Endymion and no longer had enough time to look after the collection. With the possible exception of Peet, who was in the Army Service Corps, all of the archaeologists closely involved with the Museum were working in Intelligence (Clogg this volume, 2009; Gill 2011a). Some, such as Gardner and Casson, were intelligence gatherers, while others, such as Wade, combined his job as Landing Officer, based at the busy harbour, with his counter-espionage activities (Wade 1938). As an Italian Liaison officer in Salonika approvingly noted of the British Army: "Archaeologists were found particularly useful in "I" work, because their training rendered them thoroughly capable of weighing, sifting, and co-ordinating evidence, and deducing accurate or at least reasonable conclusions.' (Villari 1922, 71). To this should be added the fact that many archaeologists had spent time in Greece before the War and could speak modern Greek and other languages. The request to use the White Tower was the suggestion of Harry Pirie-Gordon ${ }^{5}$, another archaeologist who was at that time in charge of the Eastern Mediterranean Special Intelligence Branch in Salonika (Gill 2006). The White Tower was already being used as a signalling station and so, with its harbourside location, was perhaps seen as a useful place to combine these activities.

\section{CHANCE FINDS}

The significant finds made by the British Army during this period were described in the Annual of the British School at Athens published immediately after the war, in which Gardner and Casson (1918-19) summarised the various discoveries directly 
related to the BSF Museum. Tod (1918-19) published the inscriptions, and short notes were provided by other archaeologists, including Picard (1918-19) who summarised French discoveries. The contribution by Welch (1918-19) did not relate to objects in the BSF Museum, although it did announce the identification of Dikili Tash as a prehistoric site. Cooksey and Woodward's (1918-19) contribution, with extensive annotations by Casson, also seems to have been written without reference to the BSF Museum finds. It is noteworthy that the other two curators, Peet and Wade did not contribute. By his own admission, Peet was not an active curator of the Museum, and so had little to add to the account. ${ }^{6}$ The omission of Wade is more significant because he is mentioned as the donor of 'a collection of prehistoric pottery made at various times' (Gardner and Casson 1918-19, 27). Casson, who wrote the part of the report covering Wade's tenure, was a far more qualified candidate. Major Wade, however, outranked Captain Casson, which perhaps explains why Casson was the deputy curator, despite Wade having only an amateur interest in British archaeology (Galanakis this volume; Wade 1938, 39). Rather than repeat the contents of what was an extensive, rapidly published, account of British discoveries, this paper will seek to understand how the finds came into the Museum. The Museum was intended for chance finds but also accumulated the results of what would now be seen as archaeological survey.

Unlike their French counterparts, Gardner and other archaeologists serving in the British Army did not undertake systematic excavations. Gardner visited the French excavations at Sedes (Thermi) and collaborated with French archaeologists but his duties prevented him from starting a new excavation of his own. Instead many of the British finds were made in the course of digging trenches and other fortifications. One significant find was a group of graves near Aivasil, one of which was excavated intact by Major Thomas Anderson (Morgan, this volume): his beautifully illustrated letter informing Gardner of a sixth century grave was published almost verbatim in the BSA 
article (Fig. 6.2). <INSERT FIGURE 6.2 HERE> Gardner arrived in time to assist with the excavation of an adjoining grave but it is likely that finds from other graves there were kept by soldiers. Gardner relied on officers with an interest in archaeology to keep him informed of finds and Anderson's report stands out because of the high standard of recording. In other cases the finds were simply sent in with a brief note: among the few Byzantine objects in the BSF collection are two rings and a glass bead associated with stone coffins unearthed near Stavros in the Strymon valley, but the officer who reported the find gave no further details. ${ }^{7}$

Gardner used his spare time to show people around the Museum and keep in touch with discoveries. He used to go on regular rides in the area around Thessaloniki and further afield which allowed him to follow up reports of antiquities. For instance while on a trip to the west of the British Zone he visited the Byzantine graves near Stavros from which the rings came and collected some pottery of a similar date. On the way there he had passed through Zangliveri and noticed two Hellenistic statues which had been reused in a later cemetery (Morgan, this volume). Gardner's riding companion, Captain F.P. Cockerell, ${ }^{8}$ later organised their transfer to the White Tower; in the meantime Gardner had secured the permission of Adamantiou to remove them, perhaps feeling that surface finds such as these were outside his remit. Gardner also visited Amphipolis in May 1917 as part of his naval duties, after he had relinquished control of the Museum. Here he saw the Lion of Amphipolis before its reconstruction, ${ }^{9}$ noting that: 'The lion looks a fine beast, of colossal size, but all broken up and his head lying upside down, so that one could only see the muzzle' ${ }^{10}$ There is a story that British troops later tried unsuccessfully to carry away one of the pieces (Roger 1939, 4), but this was not related to the official activities of the BSF Museum.

The French Army took a more active interest in standing architectural remains. The French initiated a study of the Arch of Galerius and St George's Basilica, where the 
French finds were kept, including trial excavations (Hebrard 1920). The only discussion of Byzantine remains in the post-war Annual of the British School at Athens was by A.M. Woodward who provided a brief account of the Byzantine fortifications at Palaio Gunaikokastro (Avret Hissar) near Kilkis (Woodward 1918-19). Inscriptions were another matter. The most high-profile find, even reported in one British newspaper, was a Roman inscription recording the assistance of Manius Sabinus Salarius in supplying the Emperor Hadrian's army (Tod 1918-19, 74). It was found by the Scots Fusiliers near Liti, north of Thessaloniki and brought to the White Tower where Gardner could study it in more detail (Fig. 6.3; Koukouvou, this volume). <INSERT FIGURE 6.3 HERE> A milestone from the time of Trajan recording the repair of a road was discovered during the course of work on the main road between Serres and Thessaloniki: rather than being despatched to the centre it was erected at the camp at Lembet, where it was known as the "Pride of the Camp" (Burr 1935, 21112) (Fig. 6.4). <INSERT FIGURE 6.4 HERE>Other inscriptions were recorded in situ: Gardner found time while on naval reconnaissance in Pieria to photograph and record a cippus (Tod 1918-19, 93). Another Roman dedication to a prominent citizen was cleaned and copied by Captain Salt and published after the war by Tod (1922). The search for inscriptions and their authoritative publication was part of a much longer tradition of epigraphic research in Greece which the Salonika Campaign served to facilitate.

\section{MOUNDS AND COLLECTORS}

Students of the British School at Athens had been active in Macedonia before the outbreak of the First World War. Alan Wace and Maurice Thompson were not the first to recognise the distinctive toumbes of Macedonia as prehistoric tell sites, but investigated them as part of their exploration of prehistoric sites in Thessaly. Whereas 
they carried out excavations at a number of sites in Thessaly, where they were assisted by T.E. Peet, ${ }^{11}$ they only visited sites in Macedonia to look for comparable pottery. They also found time to copy inscriptions which were published by A.M. Woodward, although he was not present on that expedition (Wace and Woodward 1911/12). Woodward did go on to serve in the BSF, as did Thompson. Wace remained in Athens during the War: there he served as Director of the BSA, and was attached to the British Legation where he was also involved in intelligence work (Clogg 2009, 168-170). Wace and Thompson's (1909b) short publication, updated by Wace (1913/14) following a subsequent visit, was influential because it proposed a typology of mounds and listed the sites then known. Although others had published accounts of the mounds previously, Wace and Thompson were the first to distinguish on the basis of shape between Greek burial tumuli (to which they assigned the letter A followed by a number), prehistoric tell sites (B) and later town sites (C). Wace (1913/14, 130-131) also attempted to classify the prehistoric pottery found on the surface mounds, but cautioned that excavations were needed.

Gardner relied heavily on Wace and Thompson's work in trying to make sense of the pottery deposited in the Museum. His notebook uses their numbering system both for pottery types and locations. ${ }^{12}$ One new discovery was the site known as Turk's Battery, which Cockerell and Woodward had explored. It appears that they did excavate the mound to some extent because Cockerell reported a burnt granary (Gardner and Casson 1918-19, 25). ${ }^{13}$ Sherds from the site now in the British Museum still bear the paper label written by Cockerell, as well as a marking "B. 32" (Fig. 6.5).<INSERT FIGURE 6.5 HERE> This was the code assigned to the mound by Gardner, extending Wace's (1913/14) numbering scheme. ${ }^{14}$ Gardner personally collected sherds from a number of these sites, as well as receiving donations from British soldiers. These tended to be officers with a knowledge of archaeology whose duties required them to 
move around the British Zone. One of these was Edward Forster, another former BSA student who served as an intelligence officer (Gill 2011b, 332-333). ${ }^{15}$

Some mounds were also used as military installations by the British Army. As mentioned above, a number of objects came from a mound at Lembet, where the Headquarters of the Royal Artillery was based. The mound at Akbunar was next to a military hospital. At Aivatli (Liti), defensive works were dug by soldiers from the Black Watch regiment. In this case Lieutenants A.W.R. and R.M. Don were particularly assiduous in excavating a deposit containing Middle Neolithic pottery (Dimoula this volume). Other mounds had been used as defensive points before the First World War, as the name of Turk's Battery suggests. One object was recorded as coming from Balkan War trenches in a mound near Langavuk (Cooksey and Woodward 1918-19, 54). Their wartime use as defensive points adds another layer of history to the mounds of Macedonia.

At the site of Toumba Thessaloniki (Wace's B 1) Gardner carried out a small excavation in a tunnel which had already been dug through the mound. He also collected, or was given, a small number of sherds from the French excavations at the Agricultural School (Wace's B 2). The result was a collection of sherds from many of the prehistoric mounds of Macedonia, furthering the work that Wace had done by finding new sites and using the sherds to provide an indication of date. The last curator of the BSF Museum, Major Alexander Wade, was also an active sherd collector, who dug into mounds looking for pottery (Wade 1938, 232). The collection also included material from Egypt, Melos and Malta. The Maltese pottery was donated by Theodore Zammit, who met Gardner during his stop-off on the way to Thessaloniki. ${ }^{16}$ The obsidian blades from Melos were donated by the British School at Athens. ${ }^{17}$ It is not clear how a small number of Egyptian objects, including a comb and stone tools entered the collection. The acquisition of many of these objects was due to the energy 
with which successive curators pursued their role. Gardner appears to have initiated a collecting policy for a museum in Thessaloniki which included both local archaeological remains and comparative material from elsewhere. By contrast Wade appears to have viewed the collection as a more narrowly British concern, as his subsequent actions indicate (Galanakis, this volume).

\section{FROM THE WHITE TOWER TO THE BRITISH MUSEUM}

<INSERT FIGURE 6.6 HERE>The BSF Museum was moved from the White Tower to British Headquarters at the Papapheion Orphanage in 1918, apparently to make it more accessible to British soldiers (Gardner and Casson 1919, 27) (Fig. 6.6). Major Wade had already taken over in late 1917, and a new Ephor, Eustratios Pelekidis, had been appointed at around the same time. This was the result of political changes in Greece when Eleutherios Venizelos became Prime Minister: the abdication of King Constantine I was followed by the removal of royalist officials. Stanley Casson continued to be involved with the Museum, as deputy curator, and Pelekidis was given a formal role in advising the organising committee of the Museum. ${ }^{18}$ The most significant find from this period was a fourth-century BC grave group from Karabournaki, which was found by Wade and Pelekidis following reports of discoveries in an area that had previously been excavated by the French (Wade 1938, 233; Morgan, this volume).

Another significant group of material arrived from Chauchitza, where an Iron Age and later burial site had been discovered by the YMCA in a camp supporting the British front line around Lake Doiran. Finds from Chauchitza can be recognised in photograph from the later BSF Museum (on the shelf to the left), such as a Hellenistic amphora (Fig. 6.7). <INSERT FIGURE 6.7 HERE> There are also a number of metal 
objects from Chauchitza in the BSF collection; in common with some of the other objects in the museum, these were photographed by the RAF in December 1918 (Fig. 6.8). <INSERT FIGURE 6.8 HERE> The remainder of the objects found were retained by the YMCA and donated to the National Museum of Scotland (Maitland, this volume). The Chauchitza find was the result of the expansion of the front line to the borders of Greece later in 1916: earlier finds had been made in the stronghold established around Thessaloniki.

The previous ephors, Adamantiou and Oikonomos, had been involved in establishing the BSF Museum and had visited the White Tower but were not closely involved with the collection. Pelekidis took a more active role, producing a handwritten catalogue of the collection, taking a particular interest in the pottery sherds and prehistoric tools. This was in preparation for the establishment of an archaeological museum in Thessaloniki, of which the BSF Museum had been intended to become a part. ${ }^{19}$ This plan was reported by Gardner after the transfer had happened, perhaps indicating his felings on the matter. ${ }^{20}$ Pelekidis had suggested that a representative selection of material should be sent to Britain instead (Vokotopoulou 1986; Kanatselou and Shapland 2014). Wade had actively lobbied for the collection to come to Britain, but had been rebuffed by the Imperial War Museum because they did not want to receive archaeological material. That the collection was transferred to London was due to a suggestion by Sir William Rycroft ${ }^{21}$ to the War Office Trophies Committee ${ }^{22}$ which resulted in an order being sent to Wade that the collection should be shipped to London. ${ }^{23}$ It seems likely that Wade was involved in securing this high-level permission for the collection's removal after his own informal efforts had failed.

Since the BSF Museum had been formed in order to comply with the Greek antiquities laws, the order to transfer it to Britain posed a particular problem. Realising that the Greek government would have to authorise any removal of antiquities, General Milne 
wrote to the British Minister in Athens, Lord Granville, to ask him to make a formal request. The Greek government accepted, subject to an inventory being made of the collection. The only objects which were not granted permission for export were the two inscriptions: the dedication to Sabinus and the Trajanic milestone (see above), since these were regarded as being of particular interest to the history of the region. ${ }^{24}$ Although the Greek Ambassador in London, D. Kaklamanos had lobbied the British Government to allow the collection to remain in Greece, he ultimately acquiesced in the Greek Government's decision ${ }^{25}$. The reaction of Pelekidis is not known, although stories have circulated of his unhappiness (Clogg 2009, 166; Clogg, this volume). The collection was packed into 29 crates and loaded on to a ship in September 1919, a year after the Bulgarian surrender which had ended the Macedonian Campaign. ${ }^{26}$

Major Wade followed his orders and made arrangements with the Imperial War Museum to receive the collection once it arrived in Britain, but also reminded the Secretary that his unofficial offer of the collection had been refused in $1918 .{ }^{27} \mathrm{He}$ also contacted the British Museum in the hope that it would intervene, noting that the collection was 'most unsuitable for the War Museum'. ${ }^{28,29}$ By the time the collection arrived in Britain, arrangements had been changed and the crates were despatched to the British Museum. A report to the Trustees of the British Museum, noting that the Greek Government had waived their rights to the collection, suggested that a number of people should be thanked 'on account of the excellent example set by the Salonika Force, rather than on account of the intrinsic importance of the results'. These included Wade and Pelekidis, who was thanked for his 'zealous help' and assured that the Museum contents would be 'preserved as an interesting episode in the record of the Great War'. ${ }^{30}$ The Greek government too was thanked for a 'courteous and liberal act of international comity'. ${ }^{31}$ It is apparent that the British Museum did not just regard this as a collection of antiquities but was aware of its diplomatic significance. 
A small number of other finds entered the British Museum collection through the donations of individual soldiers. Among these was a tomb group from Amphipolis excavated by Eric Gardner. ${ }^{32}$ There is a report that fishhooks found in other tombs were used for catching fish during the War, and one was subsequently donated to the Imperial War Museum, although it now cannot be located (Buller 1996). A coin hoard was also either found or bought in Macedonia and subsequently donated to the British Museum (see Appendix). Other acquisitions can be traced indirectly to soldiers of the BSF including an icon donated in 1922 (Cormack 2007, 136). Not all objects found by soldiers of the BSF came to the British Museum; only those which entered the BSF Museum. Some entered collections elsewhere (Galanakis, this volume; Maitland, this volume) or were published but their whereabouts are now unknown (Forsayeth 1920). Rather than being handed in to the Museum, some antiquities were brought back as souvenirs from Macedonia and remain in private hands.

\section{SUBSEQUENT STUDY}

The registration of the collection provides an insight into the perceived archaeological significance of the finds. All of the sculpture and jewellery, and nearly all of the weapons and complete vessels were accessioned in November 1919, with a representative sample of the potsherds and other prehistoric artifacts. In all just under 300 objects were registered. The Karabournaki helmet was put on display and illustrated in the British Museum guide (Smith 1920, 122). ${ }^{33}$ The collection arrived at a time when the value of sherds rather than complete vessels was only starting to be appreciated: the British School at Athens and Arthur Evans had donated a large number of sherds from Bronze Age Crete in 1906-1907, and a significant group of prehistoric pottery from mainland Greece was donated by the Greek Government in 1924. This allowed John Forsdyke to compile a catalogue of prehistoric Aegean 
pottery, including the registered sherds from Macedonia alongside those from elsewhere (Forsdyke 1925). ${ }^{34}$ This can be seen as the first comprehensive overview of prehistoric Aegean pottery, showing how the Bronze Age pottery of Macedonia differed from Minoan, Mycenaean and Cycladic forms.

The archaeological legacy of the BSF can be traced in the work of Stanley Casson and Walter Heurtley. Stratis Pelekidis remained an active figure in Macedonian archaeology and assisted both of them. Casson returned after the War to continue excavations at Chauchitza in 1921-1922 (Casson 1919/20-1920/21, 1923/241924/25). There he dug with Heurtley, who went on to excavate at a number of Macedonian sites until 1931. The material from these excavations remained in Thessaloniki. Both later published summary works which included the material in the British Museum, particularly the prehistoric pottery vessels (Casson 1926; Heurtley 1939). Heurtley's book in particular remains an important study of prehistoric pottery in Macedonia since it puts forward a typology based on excavated sequences. Typological studies of bronze jewellery have also incorporated objects from the BSF collection (Kilian-Dirlmeier 1979; Vasić 1982).

The BSF collection has never been published in its entirety. The Chauchitza material at the British Museum was restudied in the 1960s by Donald Bailey, who was able to reconstruct a number of tomb groups from markings on objects (Bailey 1969). As part of this study a number of objects were registered for the first time including the coins discussed in the Appendix. The remainder of the material was registered from 2011 onwards: with the advent of a digital database it has become more feasible to register groups of material of this kind and publish objects straight onto the web. ${ }^{35}$ The collection now numbers approximately 3000 objects. The majority of this recently registered material consists of pottery sherds with no markings to identify which site they came from, but a significant number has a site code, Pelekidis catalogue number 
or both. Since all of these sherds can be regarded as unstratified, even an identification of site is of limited archaeological importance. Nevertheless, the markings, particularly the Pelekidis numbers, are of historical importance since they serve as tangible links with the BSF Museum.

\section{CHARACTERISING THE COLLECTION}

<INSERT FIGURE 6.9 HERE>The recent registration of the remainder of the BSF collection means that it is possible for the first time since it was packed into crates to give an idea of its composition, and hence the archaeological activities of the British Army. It is apparent from Fig. 6.9 that the large majority of the collection comprises potsherds: since the aim of the collection was to preserve antiquities, this requires explanation. It is apparent that a number of officers such as Major Edward Forster, Captain Usborne and Major Wade actively collected sherds at sites they visited rather than acting in response to finds made in the course of military activities. The pattern of registration shows that these sherds were regarded as less important in 1919 than the stone sculptures, jewellery and other miscellaneous items which were chosen as a representative selection of the collection: over 2000 sherds remained to be registered in 2011. By contrast Pelekidis did catalogue a large number of the sherds as he attempted to develop a pottery typology: given the lack of properly excavated deposits at that time he was unable to date the local pottery, although did recognise Mycenaean and Attic imports, among others (Kanatselou and Shapland 2014).

<INSERT FIGURE 6.10 AND 6.11 HERE>Subsequent excavations mean that the pottery sequence of Macedonia is now well established: although not every sherd can be closely dated, Fig. 6.10 provides a breakdown of the collection by date. It is notable that the collection is skewed towards the Bronze Age and Iron Age: this reflects the 
concentration of activity on mounds both for military installations and by the sherd collectors. Fig. 6.11 shows the range of sites investigated, known from the site codes described above. Some of these, such as Sedes and Gona, were excavated by the French, who donated sherds to the BSF Museum. It provides a snapshot of the sites known in the British Zone in 1919. Since then the picture has changed, not least with the changing names of many sites (French 1967). New excavations have been initiated at sites such as Kalamaria (Toumba Thessaloniki) and Guvesne (Assiros) (Kotsakis and Andreou 1987; Wardle et al. 1980). Some of these sites, however, remain known only from these sherds, or at least particular phases (Dimoula this volume).

\section{DISCUSSION}

In modern terms the BSF collection began as a type of rescue archaeology but came to incorporate the results of a non-intensive surface survey. A large number of objects, particularly the high-profile finds of sculpture and jewellery, were found accidentally, but the potsherds in particular were often deliberately collected by officers with an interest in archaeology. At one end of the spectrum was Ernest Gardner, former Director of the British School at Athens, who had a professional and scholarly interest in the archaeology of the region, and at the other was officers such as Major Wade, who followed in the tradition of British amateur antiquarianism. Given that the Greek government had put pressure on the Allied Army of the Orient to establish archaeological controls in order to protect Byzantine antiquities, particularly icons, it is perhaps surprising that there is only a handful of Byzantine sherds in the BSF Museum collection and no icons. This could be seen as an indication of the difference in priorities between the classical archaeologists in the British and French armies and the concerns of the Greek government for local sensibilities. It is also likely that valuable icons remained in the hands of local populations even if they were forced to 
move from villages on the front line, although some probably were destroyed (Casson 1935, 146-147). The BSF collection instead almost entirely consisted of archaeological finds, whether unearthed in the course of trench-digging or roadbuilding, or collected more actively.

Ultimately it is difficult to disentangle the BSF Museum from the various leisure pursuits of British soldiers which were a well-known part of the Macedonian Campaign (Palmer 2009, 143-145; Wakefield and Moody 2011). Although Gardner and some of his colleagues had clear archaeological motives, other soldiers collected objects out of antiquarian interest, some of which they contributed to the collection. The White Tower collection became another of the entertainments for officers on the Salonika harbourside. Its move to British Headquarters was ostensibly to make it more accessible to soldiers, whose sporting events and pantomimes were also officially encouraged (Palmer 2009, 144). Although intended to alleviate accounts of military events, stories of archaeological discoveries in Macedonia in the British Press arguably contributed to the idea that it was an easy posting (Gardner 1918) ${ }^{36}$ It is notable that Stanley Casson's (1935) memoirs play down his archaeological activities during the War, despite being deputy curator of the Museum and an active contributor. ${ }^{37}$ Although French public opinion of the Macedonian Campaign was similar (Palmer 2009, 70), the French Army were keen to stress that archaeology was part of its scientific mission, in the spirit of Napoleon (Mendel 1918). This can be seen as a microcosm of the more laissez-faire attitude of the British to the Macedonian Campaign, both militarily and politically, compared with the interventionism of General Sarrail.

Even in 1919, when it arrived at the British Museum, the archaeological value of some of the BSF Museum collection was questioned. This can partly be seen in terms of the biases of the time towards objects of perceived aesthetic value, but this did not prevent 
the registration and publication of at least some of the potsherds. Sherds which could be associated with particular sites were a continuation of the archaeological explorations of Alan Wace but unstratified sherds from somewhere in the British Zone are indeed of limited significance. Questions have also changed. At the time these pottery styles were tied up with ideas about the 'Dorian Invasion' (Andreou et al. 2001, 282-84; Fotiadis 2001). Now excavations focus on questions of social processes rather than population movements (Andreou and Kotsakis 1997). Surface survey has become an established archaeological practice in Greece, but collection methods have improved to allow quantification rather than simply discovery of sites: the British Forces certainly did discover new sites and the rapid publication after the War was the first mention of many of them. The publication of particular finds also helped contribute to new artefact typologies. But the circumstances of discovery and recording, by soldiers engaged in an active military campaign, inevitably affected the type of information that can be extracted from them.

The historical value of the collection has increased over time: the work of the BSF, itself building on Wace's survey, was a foundation for the work of archaeologists such as Pelekidis, Casson and Heurtley. Its importance, however, is not simply for the history of archaeology in Macedonia: the objects discovered by soldiers are simultaneously archaeological artifacts and documents of their experience in Macedonia. The same can be said of objects which never reached the collection but were taken home as souvenirs. Certain finds such as the Sabinus inscription or weapons contributed to the sense that soldiers were following in the footsteps of armies millennia before: this became a trope of memoirs about the Macedonian Campaign (Burr 1935, 174; Casson 1935, 142; Collinson Owen 1919, 79; Ward Price 1918, 257). The irony of excavating at Chauchitza after the War was not lost on Stanley Casson ${ }^{38}$ : 
'As I found the graves of these well-armed warriors I could not but reflect on the progress of civilisation, for above those graves I had first before excavation to clear away countless shell fragments, cartridges and other oddments of modern war, before I could arrive, a few feet lower down, at the armaments of our ancestors'. (Casson 1935, 275)

The display of Casson's finds in the Archaeology Behind Battle Lines exhibition showed that it is as important to place such antiquities in their historical context as in their archaeological context (Adam-Veleni and Koukouvou 2012). The Sabinus inscription too, which the Greek government had insisted should stay in Greece because of its importance for local history was displayed in the exhibition in the context of its discovery by the Royal Scots Fusiliers (Koukouvou this volume). Although these remain important finds for the Iron Age and Roman past, these objects are also embedded in the modern history of the region (Stefani this volume). The objects now in the British Museum are as much part of the complicated history of twentieth century Anglo-Hellenic relations as they are fragments of the Macedonian past.

\section{CONCLUSION}

The archaeological significance of the material culture of the First World War and the potential contribution of archaeology to historical narratives of battles and campaigns are now increasingly recognised (Saunders 2002, 2010). Although the events of the War and casualty figures were well-documented, material culture, particularly in the form of souvenirs, has the potential to provide a tangible link with soldiers' personal experiences. The BSF collection materialises the activities of British soldiers with both a professional and amateur interest in archaeology who found themselves stationed in 
and around Thessaloniki between 1915 and 1919. Working with the local Ephors, Ernest Gardner and others sought to uphold Greek antiquities laws and place the finds of the British Army into the archaeological framework recently established by Wace and others. Had the collection remained in Thessaloniki, as Gardner intended, it would be one of the founding collections of the archaeological museum that Pelekidis worked so hard to establish in the years after the War (Vokotopoulou 1986). Instead its transfer to London as part of the effort of memorialising and commemorating the War emphasised its connection with the British Army. The archaeological value of the collection was not neglected: the display of some artifacts in the British Museum and the rapid publication of the important objects and sites meant that it entered the nascent archaeological narrative of Macedonia. Nearly 100 years on, its full publication on the internet allows its better integration into archaeological knowledge of the region. The centenary of the Macedonian Campaign, however, provides a time to reflect on the historical significance of the BSF collection. Just as some of the trenches and fortifications of World War One have become part of the Macedonian landscape, the antiquities found in these trenches have become part of the archaeology of the First World War. 


\section{APPENDIX: COINS FROM THE BRITISH SALONIKA FORCE EXPEDITION}

Amelia Dowler

British Museum

THE CHAUCHITZA GRAVE FINDS AND THE 'SALONIKA/THESSALONICA

ENVIRONS' HOARD

There are two groups of coins from the Thessaloniki area in the British Museum, which entered the collection as a result of the activities of the British Salonika Force. The first group, excavation coins from graves at Chauchitza, are held by the Department of Greece and Rome with the other archaeological material from the site; the second group, a small coin hoard, was purchased by the Department of Coins and Medals in 1921.

\section{Coins from Grave Groups at Chauchitza (GR 1967,0623.1-16)}

The finds of coins in Graves $\mathrm{F}$ and $\mathrm{G}$ of the Chauchitza grave group were first reported by Casson and followed by a more detailed description of their types by Bailey (1969, 37-39). Casson's description was fairly basic:

'F. Contents: 15 bronze coins of the Emperor Antoninus Pius. Nothing else was found in this grave. 
G. A grave lined with red tiles. Contents: fifteen small bronze coins, probably from the time of Constantine the Great.' (Gardner and Casson 1918-19, 37)

Bailey's analysis of the coins amongst the other finds from the graves at Chauchitza went further by attributing mints and emperors to the coins. Unfortunately by the 1960s only six of the coins from Grave $F$ and ten from Grave $G$ were found amongst the other artefacts from the site. These are described below in the catalogue. The preserved coins are very worn and in many cases the types are difficult to make out. This is especially the case with most of the inscriptions, which are worn away, and those inscriptions appearing in the catalogue in square brackets indicate this. It is now impossible to know exactly what the other coins were apart from their rough period indicated above by Casson.

The preserved coins from Grave F are mostly Antonine period (although only one actually from the reign of Antoninus Pius) but the one Severan period coin suggests that it is possible that some of the other coins (now missing) might have been third rather than second century AD. In the case of Grave G all the preserved coins are in fact from the period of Constantine's sons in the mid-fourth century AD so it is possible that the missing coins may have been earlier, i.e. actually from the reign of Constantine I. Given the fairly tight dating for the preserved coins (c.AD 350-361), it is reasonable to suppose that the missing coins were of the same period since Casson apparently classified them together.

Given the lack of full information it is probably now impossible to answer a number of questions these finds raise. Firstly, whether there was a reason that there were 15 coins in each grave or whether this is simply a coincidence (or indeed miscounting on the 
part of Casson). While it is not uncommon to find coins in graves, 15 is a high number to find in comparison with other grave deposits in the area. ${ }^{39}$ Mostly graves contain quite low numbers of coins but there are a few exceptions, especially where coins were buried in a container of some sort within the grave. A religious significance to the number 15 is a possibility: in Hebrew at least the number 15 is written in Hebrew letters as $9+6$ since $10+5$ would spell out the name of God. This raises the possibility that the graves were Jewish or early Christian. Such a possibility is hard to discuss further without the full number of coins reported by Casson. Secondly, in Grave F all the preserved coins have a Nike reverse (which may point again to a religious significance), while in Grave $G$ all but one of the preserved coins are of the FEL TEMP REPARATIO fallen horseman type. Again, it is unclear whether this is simply a coincidence or whether particular coins were chosen to be placed in the graves based on their designs. The lack of the full number of coins again hampers further discussion. Finally, the seeming mutilation of one coin out of each group may lead some to suggest that they were ritually 'killed'. GR 1967,0623.3 (Grave F) and GR 1967,0623.14 (Grave G) both show signs of bending, which could have resulted from being jabbed violently with a blunt object. Again, we do not know the condition of the missing coins from the two groups and so the significance is difficult to judge since only one coin from each group appears to have been treated in this fashion. ${ }^{40}$

\section{Grave F}

Bailey attributed all the coins from Grave F to the mint of Thessalonica during the Antonine period but one coin (2) is more likely to be from the mint of Stobi and another (3) is from the Severan period. The latter is possibly from the area of Bithynia et Pontus from similarities of design and fabric. The coins from the mint of 
Thessalonica have a standing Nike reverse and in most cases at least part of the reverse inscription survives indicating the mint. Both Stobi and various Pontic mints also featured Nike on the reverses of their coins of this period and later, which may have led to confusion over their attribution. Although no other objects were found in Grave F, Bailey correctly argues from the worn state of the coins that the grave should be dated later than the issue of the coins, perhaps to the third rather than second century. This later period for the burial of the coins is certainly confirmed by the presence of at least one early Severan period coin and given the extremely worn state of that coin it is now probable that the burial period was later in the third century or even later.

The presence of coins minted at Thessalonica is logical for the find-spot. The mint of Thessalonica became active during the Roman period and minted continuously until c.AD 268. During this period the figure of Nike was commonly used as a reverse design from the period of Claudius until the end of civic minting under Gallienus. ${ }^{41}$ It is unfortunate that it is unclear whether the missing coins were also minted at Thessalonica or whether they bear similar attributions to the two coins from further afield, namely, from Stobi and the Pontic region, as mentioned above. It is therefore difficult to tell how representative these two coins are, especially the sole third century coin from the Pontic region. Thessalonica and Stobi were the capitals of Macedonia Prima and Macedonia Salutaris respectively. The Via Egnatia is an obvious axis for the movement of coins at this period. Although neither Stobi nor northern Asia Minor were on the road itself the connections between Stobi in the west, Asia Minor in the east, and Thessalonica at the centre point of the road are suggestive. For example, finds from the site of Butrint at the far western end of the road bear witness to this movement showing coins from mints along the road and beyond, deep into Asia Minor (Moorhead et al. 2007, 79-80). Further to the east of Thessalonica a similar pattern is 
observed at Maroneia (Psoma et al. 2008, 251-253) and this is possibly the case at other sites: for example, Antonine period bronze is also reported at graves in Amphipolis (Kosmidou 2006, 415).

\section{Grave $G$}

Like the coins in Grave F, it is likely that most of the coins from Grave G were minted at Thessalonica. Two coins can be attributed to Siscia and Constantinople, reflecting the western (Stobi) and eastern (Pontic region) additions of the coin assemblage in Grave F. The Imperial mint at Thessalonica was founded under the Tetrarchy shortly after the closure of the civic mint. By the fourth century Thessalonica was an important mint and in particular an extensive coinage was struck there under Constantine I's sons. It is not surprising therefore that coins from Thessalonica are found amongst this group. Two coins are definitely attributed to Thessalonica from the clear mintmarks visible but a further six may also be from this mint although the mintmarks are now worn away. The presence of one coin each from Constantinople and Siscia may suggest other attributions for the unattributed types. All but one of the preserved coins are of the FEL TEMP REPARATIO 'fallen horseman' type, noted above. This common type is joined by another common type for this period - SPES REIPVBLICE - featuring a standing Emperor design. This coin is one of the two clearly minted at Thessalonica. Its local availability may be why it was included in the grave instead of another of the fallen horseman type supposing of course that there had been any deliberate selection of reverse types. The coins in general are very common in the area. At Butrint coins of this type from Thessalonica and Constantinople were found (Moorhead 2007, 293) and in two thirds of cases the coins were recovered in contexts that suggest that they were lost in the fifth century rather than the fourth. This 
points to the common use of bronze coins at periods much later than their date of issue (i.e. residuality). The worn appearance of the coins from Grave G, like those from Grave F, is an important indicator of this phenomenon.

\section{CATALOGUE $^{42}$}

<INSERT FIGURE 6.12 HERE>

Grave F (GR 1967,0623.1-6) (Fig. 6.12)

Thessalonica

\section{Antoninus Pius (AD 138-150)}

Obverse: [AYTOKPATSP ANTSNINOS] Laureate head of Antoninus Pius wearing cuirass and paludamentum, right.

Reverse: $[\Theta E \Sigma \Sigma A \Lambda O N I K E \Omega N]$ Nike advancing right, holding wreath and palmbranch.

$1 \quad 1967,0623.1 \quad$ AE $\quad 13.43 \quad 12 \quad 25$

Bailey (1969) F1; RPC4 4300; (Touratsoglou 1988,190, no. 7-8)

\section{Commodus (AD 166-177)}

Obverse: [AYTOK M AYP KOMM ANTSNEINON] Laureate bust of Commodus (short beard) wearing cuirass and paludamentum, right.

Reverse: $[\Theta \mathrm{E}] \Sigma \Sigma \mathrm{A} \Lambda \mathrm{O}[\mathrm{NIKE} \Omega \mathrm{N}]$ Nike advancing right, holding wreath and palm-branch. 
$2 \quad 1967,0623.4 \quad$ AE $12.96 \quad 12 \quad 28 \quad$ Bailey F4; Nike left; cf.

Touratsoglou p.194, 1-2

(AD 184-188)

Obverse: [AYTOK(P) M AYP KOMM ANTSNEINON] Laureate head of Commodus, right.

Reverse: $[\Theta E \Sigma \Sigma A \Lambda O N(E) I K E \Omega N]$ Nike advancing right, holding wreath and palm-branch.

$3 \quad 1967,0623.6$ AE $10.076 \quad 25$ Bailey F6; cf. RPC4 8290; cf. Touratsoglou p.194-5, 6-11

\section{(AD 188-192)}

Obverse: [AVT K $\mathrm{M}$ AYP KOMM ANTSNEINON] Laureate bust of Commodus wearing cuirass and paludamentum, right.

Reverse: $\quad \Theta E \Sigma \Sigma \mathrm{A} \Lambda \mathrm{ON}[\mathrm{IKE} \Omega \mathrm{N}]$ Nike advancing right, holding wreath and palmbranch; $\quad$ to right, crescent.

$4 \quad 1967,0623.5$ AE $11.90 \quad 6 \quad 26 \quad$ Bailey $\quad$ F5; $\quad$ RPC4 8306; Touratsoglou 43

Stobi

Marcus Aurelius (AD 161-180)

Obverse: [IMP M AV ANTONINVS] Radiate head of Marcus Aurelius, right. 
Reverse: $\quad[S-$ TOBEN - SIVM] Nike-Nemesis advancing left, holding cubit, wreath and palm-branch; to left, at her feet, wheel.

$5 \quad 1967,0623.2 \quad$ AE $\quad 9.47 \quad 12 \quad 26 \quad$ Bailey F2; RPC4 7839; Josifovski 104.

Uncertain (Pontic?) Mint

Severan dynasty (Caracalla or Geta?) Early 3rd century AD

Obverse: $\quad[\ldots]$ Bare-headed bust of youthful Severan wearing cuirass and paludamentum, right.

Reverse: $\quad[\ldots]$ Nike advancing left, holding wreath and palm-branch.

$6 \quad 1967,0623.3 \quad$ AE $\quad 8.23 \quad 6 \quad 30 \quad$ Bailey F3

<INSERT FIGURE 6.13 HERE>

Grave G (GR 1967,0623.7-16) (Fig. 6.13)

Thessalonica

Constantius II (AD 25 December 350-6 November 355)

Obverse: [D N C]ONSTAN - [TIVS P F AVG] Pearl-diademed bust of Constantius II, right, draped and cuirassed.

Reverse: FEL [TEMP REPARATIO] Helmeted soldier to left, shield on left arm, spearing falling horseman; shield on ground at right. Horseman turns to face soldier and extends left arm. $\Gamma-/ /$ SMTS 


\section{(AD 6 November 355-Summer 361)}

Obverse: [D N CON]STAN - [TIVS P F AVG] Pearl-diademed bust of Constantius II, right, draped and cuirassed.

Reverse: SPE[S REI] - PVBLICE Emperor, helmeted and in military dress, standing left, holding globe and spear. * - //SMTSA

$8 \quad 1967,0623.16$ AE $\quad 1.00 \quad 12 \quad 15 \quad$ Bailey G10; L1691; RIC8 215

Constantinople

\section{Constantius II (AD 6 November 355-3 November 361)}

Obverse: [D N] CONS[TAN - TIVS P F AVG] Pearl-diademed bust of Constantius II, right, draped and cuirassed.

Reverse: $\quad$ FEL TEMP RE - PARATIO Helmeted soldier to left, shield on left arm, spearing falling horseman; shield on ground at right. Horseman turns to face soldier and extends left arm. CONS[.]•

$9 \quad 1967,0623.8 \quad$ AE $\quad 1.62 \quad 12 \quad 18 \quad$ Bailey G2; L2041; RIC8 135

Siscia

Julian Caesar (AD 6 November AD 355-Summer AD 361)

Obverse: D N IVLIAN - [VS NOB C] Bareheaded bust of Julian Caesar, right, draped and cuirassed. 
Reverse: FEL TEMP [REPARATIO] Helmeted soldier to left, shield on left arm, spearing falling horseman; shield on ground at right. Horseman wears pointed cap, turns to face soldier and extends left arm. M - //ASIS[.]

$10 \quad 1967,0623.15$ AE $\quad 1.88 \quad 6 \quad 17 \quad$ Bailey G9; L1241; RIC8 382

Uncertain Mints

\section{Constantius II (issues of $c$.AD 350-61)}

Obverse: $\quad$ D N CONSTAN - TIVS P F AVG Pearl-diademed bust of Constantius II, right, draped and cuirassed.

Reverse: $\quad$ FEL TEMP REPARATIO Helmeted soldier to left, shield on left arm, spearing falling horseman; shield on ground at right. Horseman turns to face soldier and extends left arm. Mintmark ??//?

$11 \quad 1967,0623.10$ AE $2.59 \quad 12 \quad 18 \quad$ Bailey G4; RIC8? [.]N CONST $[\ldots] /[\ldots]$

$12 \quad 1967,0623.11$ AE $2.17 \quad 12 \quad 18 \quad$ Bailey G5; RIC8? [...]STAN - TIVS P F AVG / [...]M[...]

$13 \quad 1967,0623.12$ AE $\quad 1.51 \quad 7 \quad 16 \quad$ Bailey G6; RIC8? No inscription visible $14 \quad 1967,0623.13$ AE $2.12 \quad 6 \quad 17 \quad$ Bailey G7; RIC8? DN $\operatorname{CONS}[\ldots] /[\ldots] \mathrm{TEMP}[\ldots]$

$15 \quad 1967,0623.14$ AE $\quad 1.78 \quad 12 \quad 15 \quad$ Bailey G8; RIC8? No inscription visible 
Obverse: $\quad[\ldots]$ CONSTAN - TIVS N[OB C] Bareheaded bust of Constantius Gallus, right, draped and cuirassed.

Reverse: [FEL TEMP REPARATIO] Helmeted soldier to left, shield on left arm, spearing falling horseman; shield on ground at right. Horseman turns to face soldier and extends left arm. Mintmark ??//?

$16 \quad 1967,0623.7 \quad$ AE $\quad 1.09 \quad 12 \quad 17 \quad$ Bailey G1; RIC8?

\section{SALONIKA/“THESSALONICA ENVIRONS” HOARD (IGCH 413) (CM}

$1921,0715.1-13)^{43}$

In 1921 the Department of Coins and Medals purchased a small hoard of bronze coins. Its purchase is recorded in three places amongst the archive documents of the department: the notification of the purchase, the approval of the bill, and the acquisition register. In the first two the thirteen coins are described as ' 13 bronze coins of Alexander the Great, being a small find made in Macedonia' purchased from 'L.H. Miller' for the sum of 1 pound 1 shilling. In the acquisition register for Greek coins, the vendor is described as 'L.M. Miller' and the coins as 'a find (complete) from the neighbourhood of Salonika' and the coins are correctly attributed to Philip II (5 coins) and Alexander III (8 coins). Although described briefly in Noe (1925 and 1937, nos. 631 and 898 respectively) the first full description of the coins published was in Price's summary of hoards in the British Museum $(1969,8-9)$ and then his further notes on the Alexander bronzes in the hoard (1991, types 373, 376-7, 382, 385-6). Price $(1969,8)$ describes the hoard as the 'Salonika Find of $c .1918$ ' and it is later described as the 'Thessalonica Environs' hoard in IGCH (1973, no. 413). 
In Price's article $(1969,8)$ he describes the find as 'made during military operations in the $1^{\text {st }}$ World War' and he dates the find to $c .1918$. Additionally Price claims in unpublished notes to this article that the circumstances of the find are unknown but apparently the find is complete. There are two L.H. Millers (and not L.M.) listed amongst the medal cards now housed at the National Archive in Kew. One was a seaman but the other served as a second lieutenant, then lieutenant with the Hampshire regiment, the 10th battalion of which was part of the Salonika expedition. It is possible therefore that this is the person who bought or found the hoard while in the Salonika region. Miller is otherwise unknown and does not appear to have sold or donated any other material to the Museum.

Price $(1969,9)$ links the Salonika/Thessalonica Environs hoard with the period just before Cassander started to mint his own bronze coins in c.310 BC and later suggests a date of deposit of the hoard of c.315-310 BC (Price 1991, 57). Due to the inclusion of the late Alexander issues, he dated the hoard a little later than the Drama hoard (IGCH 1973, no. 404; Bellinger 1964, 37-52; SNG ANS nos. 830-1002 passim with section introduction), which included $c .785$ bronze coins found in 1931. The date for the burial of the Drama hoard has shifted over the years however particularly after the publication of the American Numismatic Society's collection of Philip II coins, which includes a large number of coins from the hoard. The original date of $c .325-310$ suggested by IGCH 1973, no. 404) has been twice revised to $c .323-320$ BC or a little later (Price 1991, 53) and then to after 306/5-301/0 BC from the analysis of one bronze coin of Lysimachus found amongst the hoard (SNG ANS note on no. 997). This last dating places the Drama hoard more or less contemporaneously with the Salonika hoard. Other hoards containing bronze coins from this period and area still appear to have been a little earlier, for example the Mogilovo hoard (IGCH 1973, no. 
844; Dimitrov 1986), Pelin (CH2, 1976, no. 53), and East Macedonia (CH3, 1977, no. 23; Karamesini-Oikonomidou 1976, 5). See also Price 1991, 53-54 for summaries of the contents of these hoards.

The Philip bronzes (especially nos. 1-3 and 5) are much more worn than the Alexanders suggesting that although the Philips had been circulating since their issue, the hoard was probably gathered fairly soon after the issue of the Alexanders. Since all have approximately the same diameter and style of flan there is no reason why they should have not circulated together for a short period at least before burial. Both issues are posthumous - the production of the Philips in c.345-310BC and of the Alexanders in c.325-310BC. By 1991, in a wider analysis of the coins of Alexander III and Philip Arrhidaeus, Price had concluded that the posthumous Alexander coins at least were perhaps minted in Eastern Macedonia, possibly Amphipolis (Price 1991, 116-117). The mint for the Philip bronzes is unclear but given the find-spot evidence it is likely to have also been in Macedonia (see SNG ANS section introduction to nos. 8301005).

\section{CATALOGUE}

\section{<INSERT FIGURE 6.14 HERE>}

Philip II (Posthumous c.345-310BC) (CM 1921,0715.1-5) (Fig. 6.14)

Obverse: $\quad$ Head of Apollo, wearing taenia, right.

Reverse: $\quad$ ФІАІППОҮ Horseman right; below, mintmark. 


$\begin{array}{lrlcccc}1 & 1921,0715.1 & \text { Bucranium } & 6.14 & 9 & 19 & \text { Price }(1969,9) 1 \\ 2 & 1921,0715.2 & \text { Bucranium } & 5.24 & 12 & 17.5 & \text { Price }(1969,9) 2 \\ 3 & 1921,0715.4 & \text { Causia } & 5.74 & 9 & 17 & \text { Price }(1969,9) 5 \\ 4 & 1921,0715.5 & \text { Barley-ear } & 5.87 & 11 & 17.5 & \text { Price }(1969,9) 4\end{array}$

Obverse: Head of Apollo, wearing taenia, left.

Reverse: $\quad$ ФІАІППОҮ Horseman right; below, mintmark.

$5 \quad 1921,0715.3 \quad$ Caduceus $\quad 6.44 \quad 6 \quad 18.5 \quad$ Price $(1969,9) 3$

\section{Alexander III (Posthumous c.325-310BC) (CM 1921,0715.6-13)}

Obverse: $\quad$ Head of Herakles, right.

Reverse: $\quad$ BA Above, bow and quiver left; below, club left; below, mintmark.

$6 \quad 1921,0715.6 \quad$ Snake $\quad 5.69 \quad 12 \quad 17.5 \quad$ Price (1991) 385; (1969,

9) 10

$7 \quad 1921,0715.7 \quad$ Trident $\quad 5.87 \quad 5 \quad 17 \quad$ Price (1991) 386a; (1969,

9) 11

$8 \quad 1921,0715.8$ Thunderbolt $5.82 \quad 12 \quad 16.5 \quad$ Price (1991) 376d; (1969,

9) 13

$9 \quad 1921,0715.10$ Branch $\quad 5.82 \quad 3 \quad 17.5$ Price (1991) 377d; (1969,

9) 9

$10 \quad 1921,0715.11$ Jerboa $\quad 6.43 \quad 11 \quad 17 \quad$ Price (1991) 382c; (1969,

9) 7 
$11 \quad$ 1921,0715.12 Jerboa $\quad 6.16 \quad 8 \quad 17 \quad$ Price (1991) 382d; (1969,

9) 8

Obverse: $\quad$ Head of Herakles, right.

Reverse: $\quad$ BA Above, bow and quiver left; below, club right; below, mintmark.

12 1921,0715.9 Thunderbolt $5.96 \quad 7 \quad 18 \quad$ Price (1991) 376e; (1969,

9) 12

Obverse: $\quad$ Head of Herakles, right.

Reverse: $\quad$ BA Above, club right; below, bowcase left; between B - A, mintmark.

13 1921,0715.13 Thunderbolt $4.47 \quad 2 \quad 17$ Price (1991) 373a; (1969,

9) 6 


\section{REFERENCES}

Adam-Veleni, P. and Koukouvou, A. (eds.) 2012.Archaeology behind Battle Lines. In Thessaloniki of the Turbulent Years 1912-1922, Catalogue of the exhibition,

Thessaloniki Archaeological Museum, 24 November 2012 - 30 May 2014 (Thessaloniki).

Andreou, S., Fotiadis, M. and Kotsakis, K. 2001. 'The Neolithic and Bronze Age of Northern Greece', in Cullen, T. (ed.), Aegean Prehistory: A Review (American Journal of Archaeology supp. vol. 1; Boston), 259-319.

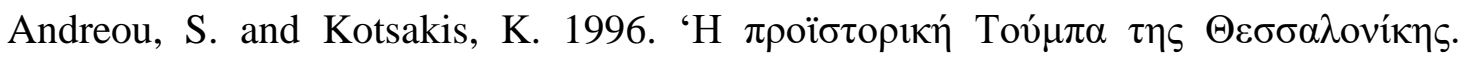

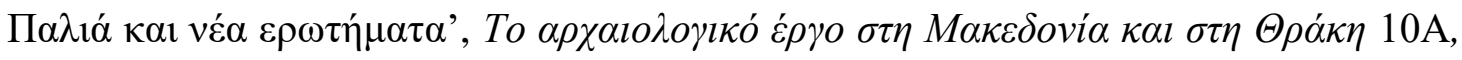
$369-87$.

Bailey, D. 1969. 'Some grave groups from Chauchitza in Macedonia', Opuscula Atheniensia 9, 21-40.

Bellinger, A.R. 1964. 'Philippi in Macedonia', American Numismatic Society Museum Notes 11, 29-52.

Buller, F. 1996. 'The Macedonian Fly', The American Fly Fisher 22 (4), 2-9.

Burr, M. 1935. Slouch Hat (London). 
Carson, R.A.G., Hill, P.V., and Kent, J.P.C. 1978. Late Roman bronze coinage: Part I: The bronze coinage of the house of Constantine AD 324-346; Part II: Bronze Roman Imperial coinage of the later Empire, 2nd edn (London).

Casson, S. 1916. 'Note on the ancient sites in the area occupied by the British Salonika Force during the campaign 1916-1918', Bulletin de correspondance hellénique 40, 293-97.

Casson, S. 1919/20-1920/21. 'Excavations in Macedonia', Annual of the British School at Athens 24, 1-33.

Casson, S. 1923/24-1924/25. 'Excavations in Macedonia - II', Annual of the British School at Athens 26, 1-29

Casson, S. 1926. Macedonia, Thrace and Illyria: their relations to Greece from the earliest times down to the time of Philip son of Amyntas (Oxford).

Casson, S. 1935. Steady Drummer (London).

Chryssanthaki-Nagle, K. 2006. 'La monnaie funéraire dans la nécropoles de Macédoine', in Guimier-Sorbets, A.-M., Hatzopoulos, M.B., and Morizot, Y. (eds.), Rois, cites, necropolis: Institutions, rites et monuments en Macédoine (Athens), 89103.

Clogg, R. 2009. 'Academics at War: The British School at Athens during the First World War', in Llewellyn Smith, M., Calligas, E. and Kitromilides P. (eds.), Scholars, 
Travels, Archives: Greek History and Culture through the British School at Athens. Proceedings of A Conference Held at the National Hellenic Research Foundation, Athens, 6-7 October 2006 (British School at Athens Studies 17; London), 163-77.

Collinson Owen, H. 1919. Salonica and After: The Sideshow that Ended the War (London).

Cooksey, W. and Woodward, A.M. 1918-19. 'Macedonia IV. Mounds and other Ancient Sites in the Region of Macedonia', Annual of the British School at Athens 23, $51-63$.

Cormack, R. 2007. Icons (London).

Dimitrov, K. 1986. 'Trésor avec des monnaies de bronze de Philippe II, d'Alexandre le Grand et de Seuthès du village de Mogilovo, department de Stara Zagora', Archaeologia 28, 32-40.

Forsayeth, G. 1920. 'A Few Antiquities from Macedonia', Man 20, 52-55.

Forsdyke, J. 1925. Catalogue of the Greek and Etruscan Vases in the British Museum, I, 1. Prehistoric Aegean Pottery (London).

Fotiadis, M. 2001. 'Imagining Macedonia in Prehistory, ca. 1900-1930', Journal of Mediterranean Archaeology 14 (2), 115-135. 
French, D. 1967. Index of Prehistoric Sites in Central Macedonia and Catalogue of Sherd Material in the University of Thessaloniki (Athens, privately circulated).

Gardner, E.A. 1918. 'Archaeological Discoveries in Macedonia', Times Literary Supplement, March 28 1918, 150.

Gardner, E. and Casson, S. 1918-19. 'Macedonia II. Antiquities found in the British zone 1915-1919', Annual of the British School at Athens 23, 10-43.

Gill, D. 2006. 'Harry Pirie-Gordon: Historical research, journalism and intelligence gathering in the Eastern Mediterranean (1908-18)', Intelligence and National Security $21(6), 1045-59$.

Gill, D. 2011a. 'Excavating Under Gunfire: Archaeologists in the Aegean During the First World War', Public Archaeology 10 (4), 187-99.

Gill, D. 2011b. Sifting the Soil of Greece: The Early Years of the British School at Athens (1886-1919) (Bulletin of the Institute of Classics Studies, supp. vol.111; London).

Haselgrove, C. and Wigg-Wolf, D. (eds.) 2005. Iron Age Coinage and Ritual Practices (Studien zu Fundmünzen der Antike 20; Mainz).

Hebrard, E. 1920. 'Les travaux du Service archéologique de l'armée d'Orient à l'arc de triomphe «de Galère» et à l'église Saint-Georges de Salonique', Bulletin de Correspondance Hellénique 44, 5-40. 
Heurtley, W.A. 1939. Prehistoric Macedonia (Cambridge).

Howgego, C. and Heuchert, V. n.d. Roman Provincial Coinage Vol. IV: The Antonines (AD 138-192). (Available online: <http://rpc.ashmus.ox.ac.uk/coins/> accessed July 2014)

Josifovski, P. 2001. Roman Mint of Stobi (Skopje).

Kanatselou, A. and Shapland, A.J. 2014. Eustratios Pelekidis and the British Salonika Force Museum, in Stefani, E., Merousis, N. and Dimoula, A. (eds.). A Century of Research in Prehistoric Macedonia, Proceedings of the International Conference, Archaeological Museum of Thessaloniki, 22-24 November 2012 (Thessaloniki), 91100.

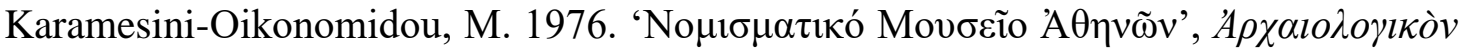
$\Delta \varepsilon \lambda \tau i o v 31 \mathrm{~B}, 4-6$.

Kent, J.P.C. 1981. The Roman Imperial Coinage, vol. VIII: The family of Constantine I, AD 337-364 (London).

Kiernan, P. 2001. 'The Ritual Mutilation of Coins on Romano-British Sites', British Numismatic Journal 71, 18-33.

Kilian-Dirlmeier, I. 1979. Anhänger in Griechenland von der mykenischen bis zur spätgeometrischen Zeit (Prähistorische Bronzefunde, Abt. 11,2; Munich). 
Kosmidou, E. 2006. 'Greek Coins from the Eastern Cemetery of Amphipolis', Numismatic Chronicle Seventh Series, 166, 415-431.

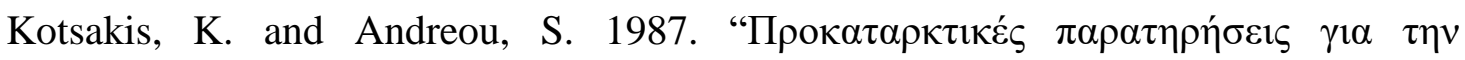

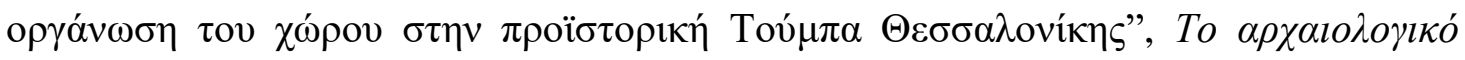

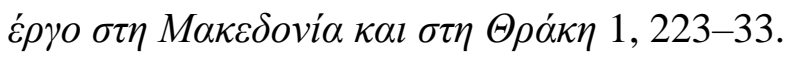

Mendel, G. 1918. 'Les travaux du service archéologique de l'armée française d'Orient', Comptes rendus des séances de l'Académie des Inscriptions et Belles-Lettres 62e année, N. 1, 9-17.

Moorhead, T.S.N. 2007. 'The Ancient and Early Mediaeval Coins from the Triconch Palace at Butrint, c. 2nd century BC - c. AD 600', Numismatic Chronicle Seventh Series 167, 287-304.

Moorhead, T.S.N., Gjongecaj, S., and Abdy, R. 2007. 'Coins from the Excavations at Butrint, Diaporit and the Vrina Plain' in Hansen, I.L. and Hodges, R. (eds.), Roman Butrint: An Assessment (Oxford), 78-94.

Noe, S.P. 1925. A Bibliography of Greek Coin Hoards (Numismatic Notes and Monographs 25; New York).

Noe, S.P. 1937. A Bibliography of Greek Coin Hoards, 2nd edn (Numismatic Notes and Monographs 78; New York). 
Palmer, A. 2009. The Gardeners of Salonika: The Macedonian Campaign 1915-1918 (London).

Picard, C. 1918-19. 'Macedonia I. Les Recherches archéologiques de l'Armée Française en Macédoine, 1915-1919', Annual of the British School at Athens 23, 1-9.

Price, M.J. 1969. 'Greek Coin Hoards in the British Museum', Numismatic Chronicle Seventh Series 9, 1-14.

Price, M.J. 1976. Coin Hoards II (London).

Price, M.J. 1977. Coin Hoards III (London).

Price, M.J. 1991. The Coinage in the Name of Alexander the Great and Philip Arrhidaeus (Zurich and London).

Psoma, S., Karadima, C., and Terzopoulou, D. 2008. The Coins from Maroneia and the Classical City at Molyvoti (Meletemata 62; Athens)

Rey, L. 1916. 'Observations sur les sites préhistoriques et protohistoriques de la Macédoine', Bulletin de Correspondance Hellénique 40, 257-292.

Rey, L. 1917-19. 'Observations sur les premieres habitats de la Macédoine. Recueillies par le Service Archéologique de l'Armée d'Orient 1916-1919 (Région de Salonique)', Bulletin de Correspondance Hellénique 41-43, 1-310. 
Roger, J. 1939. 'Le Monument au lion d'Amphipolis', Bulletin de Correspondance Hellénique 63, 4-42.

Saunders, N. 2002. 'Excavating Memories: Archaeology and the Great War, 19142001', Antiquity 76(1), 101-8.

Saunders, N. 2010. Killing Time: Archaeology and the First World War, $2^{\text {nd }}$ edn. (Stroud).

Smith, A.H. 1920. A Guide to the Department of Greek and Roman Antiquities in the British Museum, 5th edn (London).

Thompson, M., Mørkholm, O, and Kraay, C.M. 1973. An Inventory of Greek Coin Hoards (New York).

Tod, M.N. 1918-19. 'Macedonia. VI. Inscriptions', Annual of the British School at Athens 23, 67-97.

Tod, M.N. 1922. 'Greek Inscriptions from Macedonia', Journal of Hellenic Studies 42, $167-83$.

Touratsoglou, I. 1988. Die Münzstätte von Thessaloniki in der römischen Kaiserzeit (Berlin).

Troxell, H. 1994. Sylloge Nummorum Graecorum: The Collection of the American Numismatic Society Part 8 Macedonia II: Alexander I-Philip II (New York). 
Tselekas, P. 1996. 'Grave Hoards of Greek Coins from Greece', Numismatic Chronicle Seventh Series 156, 249-259

Vasić, R. 1982. 'Ein Beitrag zu den Doppelnadeln im Balkanraum', Praehistoriche Zeitschrift 57, 220-57.

Villari, L. 1922. The Macedonian Campaign (London).

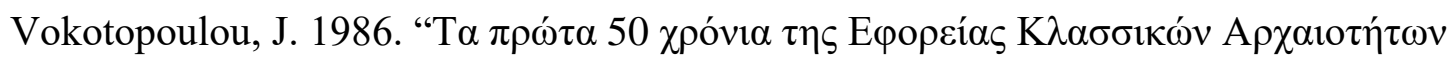

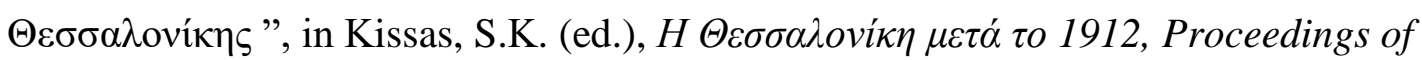
the Symposium, Thessaloniki, 1-3 November 1985 (Thessaloniki), 1-65.

Wace, A.J.B. 1913/14. 'The Mounds of Macedonia', Annual of the British School at Athens 20, 123-32.

Wace, A.J.B and Thompson, M.S. 1909a. 'Early Civilization in North Greece: Preliminary Report on Excavations in 1909', Liverpool Annals of Archaeology and Anthropology 2, 149-58.

Wace, A.J.B and Thompson, M.S. 1909b. 'Prehistoric Mounds in Macedonia', Liverpool Annals of Archaeology and Anthropology 2, 159-64.

Wace, A.J.B and Woodward, A.M. 1911/12. 'Inscriptions from Upper Macedonia', Annual of the British School at Athens 18, 166-188 
Wade, A. G. 1938. Counterspy (London).

Wakefield, A. and Moody, S. 2011. Under the Devil's Eye: The British Military Experience in Macedonia 1915-1918 (Barnsley).

Walters, H.B. 1928. A Guide to the Department of Greek and Roman Antiquities in the British Museum, 6th edn (London).

Ward Price, G. 1918. The Story of the Salonica Army (London).

Welch, F.B. 1918-19. 'Macedonia III. Prehistoric pottery', Annual of the British School at Athens, 44-50.

Woodward, A.M. 1918-19. 'Macedonia. VII. The Byzantine Castle of Avret-Hissar', Annual of the British School at Athens 23, 98-103. 
${ }^{1}$ This article is dedicated to the memory of Donald Bailey (1931-2014) who took a particular interest in the study of the British Salonika Force material, among his many other contributions during his long career as a curator in the Department of Greece and Rome.

${ }^{2}$ A contemporary suggested that the reason Gardner joined the navy rather than the army was because of his facial hair; soldiers were not permitted to have beards (Burr 1935, 109).

${ }^{3}$ Diary of Ernest Gardner, 17 February 1916. UCL Special Collections

${ }^{4}$ For a list of archaeologists associated with the British School at Athens and their wartime service see Gill (2011b).

${ }^{5}$ Diary of Ernest Gardner, 10 February 1916. UCL Special Collections.

6 'There is, I think, nothing I could have added to what Professor Gardner will have told you concerning the Salonica things, as I believe the collection was not added to after he left, at least not in my time'. Letter from Peet to Pryce, 24 November 1919. Department of Greece and Rome Letter Book.

${ }^{7}$ Excavated by the $80^{\text {th }}$ Infantry Brigade. Telegram. Department of Greece and Rome Miscellaneous Papers.

${ }^{8}$ Grandson of Charles Robert Cockerell, noted architect and archaeologist.

${ }^{9}$ Thucydides' account of the Battle of Amphipolis was well known among British officers, who called the location of the lion 'Brasidas' tomb' on their maps (Ward Price 1918, 299).

${ }^{10}$ Diary of Ernest Gardner, 7 May 1917. UCL Special Collections.

${ }^{11}$ Peet studied the pottery from Tsani Maghoula (Wace and Thompson 1909a, 149).

${ }^{12}$ Notes for Salonica Museum Catalogue. Department of Greece and Rome Miscellaneous Papers. 
${ }^{13}$ What he called an 'early village tragedy', letter from Cockerell to Gardner. BM Archive.

${ }^{14}$ Cooksey and Woodward (1918-19) also extended Wace's scheme but did not use the same numbering system, seemingly without reference to Gardner's notebook and the BSF Museum collection. Whereas Gardner added 12 new prehistoric mounds, Cooksey and Woodward listed 4 prehistoric mounds and two later sites which were not on Wace's list.

${ }^{15}$ Forster collected sherds from a number of sites. Letter from Forster to Gardner, 17 May 1916. Department of Greece and Rome Miscellaneous Papers

${ }^{16}$ Zammit is credited as donor in the Department of Greece and Rome Register. The visit is recorded in the Diary of Ernest Gardner, September 28 1916. UCL Special Collections.

${ }^{17}$ Department of Greece and Rome register. Bosanquet, the excavator of Phylakopi worked in Salonika but it is not clear if he donated these objects.

${ }^{18}$ A.G. Wade to R. Baden Powell, September 1918. Department of Greece and Rome Letter Book.

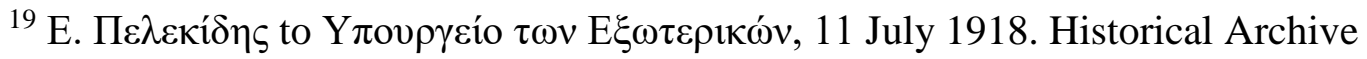
A.M.Th.-16th E.P.C.A. (1918/0055/143)

20 'It was our hope that the collection would be retained in Salonika, where it should form the nucleus of a local Macedonian museum, instead of being transferred to Athens or any other centre' (Gardner and Casson 1918-19, 43).

${ }^{21}$ Deputy Quartermaster-General, one of the most senior officers in the British Salonika Force

${ }^{22}$ The terms of reference of the War Office Trophies Committee were: 'To deal with all questions connected with the distribution of trophies and to watch the interests of the Imperial War Museum in consultation with the Museum Committee'. They dealt 
almost exclusively with the distribution of military material to local and national institutions in the British Empire. Martin Conway, Director of the Imperial War Museum was a member of the committee. War Office Trophies Committee Interim Report. The National Archives: WO 33/3122.

${ }^{23}$ J.S.U. Rusbridger to A.G. Wade, 23 April 1919, Department of Greece and Rome Miscellaneous Papers.

${ }^{24}$ Note Verbale from Ministère des Affaires Etrangères to British Legation at Athens, 24 June 1919. The National Archives: FO 286/705.

${ }^{25}$ Letters from D. Kaklamanos to Earl Curzon, 2 May 1919 and 9 July 1919. The National Archives: FO 286/705.

${ }^{26}$ Letter from William Mallandain to Major Wade, 16 September 1919. Department of Greece and Rome Miscellaneous papers.

${ }^{27}$ Letter from Major Wade to the Secretary of the Imperial War Museum, 12 September 1919. Department of Greece and Rome Letter Book.

${ }^{28}$ Letter from Major Wade to Reginald Smith, 17 September 1919. Department of Greece and Rome Letter Book.

${ }^{29}$ A view shared by Alan Wace, who annotated the letter of thanks from the British Museum expressing his approval. Letter from F.G. Kenyon to Earl Granville, 21 November 1919. The National Archives: FO 286/705.

${ }^{30}$ F.G. Kenyon to E. Pelekidis, 15 December 1919, British Museum Central Archive, Trustees' Letter Book.

${ }^{31}$ F.G. Kenyon to Foreign Office. 14 November 1919. British Museum Central Archive, Trustees' Letter Book.

${ }^{32}$ Served in the Royal Army Medical Corps. No relation to Ernest Gardner.

${ }^{33}$ The 1928 guidebook notes stone tools and jewellery from Macedonia, suggesting that a selection of these objects were put on display (Walters 1928). 
${ }^{34}$ Sir John Forsdyke, curator in the Department of Greek and Roman Antiquities at the British Museum, and later Director of the British Museum, also served in Macedonia during the First World War in the Royal Artillery but appears to have had little to do with the BSF Museum.

${ }^{35}$ Available online:

http://www.britishmuseum.org/research/collection_online/search.aspx accessed April 2016.

${ }^{36}$ For example Acrhæology [sic] in War: A 2000-Year-Old Tomb near Salonika. Illustrated London News, November 11, 1916, p. 571

${ }^{37}$ Casson donated sherds from a number of sites. Letter from Casson to Gardner, 14 October 1916. Department of Greece and Rome Miscellaneous Papers.

${ }^{38}$ Casson died in a plane crash in Greece in 1944 while servings as an intelligence officer in the British Army.

${ }^{39}$ See for example, Tselekas (1996) for pre-Imperial period graves from Macedon and Thessaly and for pre-Imperial period practices in general see Chryssanthaki-Nagle (2006).

40 See Kiernan (2001) and Haselgrove and Wigg-Wolf (2005) for western contexts for coin mutilation in grave or votive contexts.

${ }^{41}$ See Touratsoglou (1988) for the full range of types.

${ }^{42}$ Abbreviations: Bailey $=$ Bailey 1969; L = Carson, Hill, and Kent 1978; Josifovski = Josifovski 2001; RIC8 = Kent 1981; RPC4 = Howgego and Heuchert n.d.; Touratsoglou $=$ Touratsoglou 1988.

${ }^{43}$ CH2 = Price 1976; CH3 = Price 1977; IGCH = Thompson, Mørkholm and Kraay 1973; SNG ANS = Troxell 1994 